\title{
A theological evaluation of God business: A case study of the Prophetic Healing and Deliverance Ministries of Zimbabwe
}

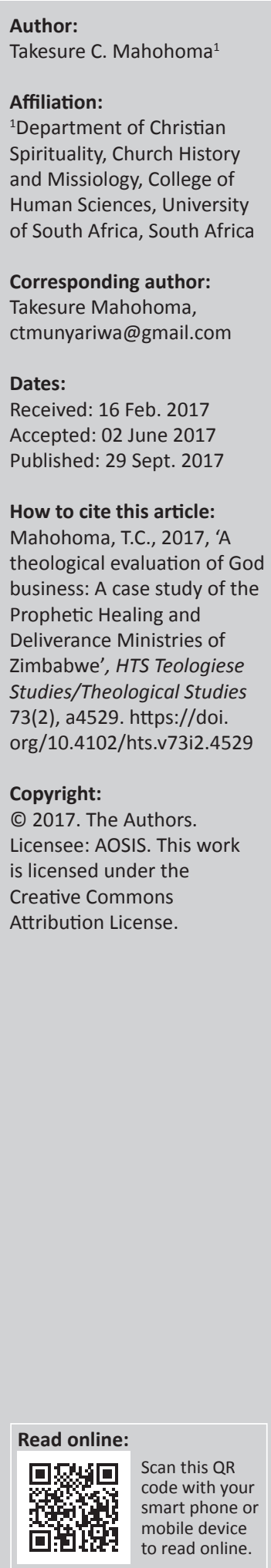

\begin{abstract}
The issue of wealth accumulation by some leaders of neo-prophetic movements is a burning issue in the world, and Zimbabwe in particular. The emphasis on financial prosperity and health restoration as a fruit of commitment to prayer and faith has taken precedence within the Gospel. Recent insights from researchers have shown that Walter Magaya of Prophetic Healing and Deliverance (PHD) Ministries is among the richest Zimbabweans, while the country is facing economic doldrums and high unemployment. This article provides us with an example of research on how people grasp the Gospel, suffering and Christian teaching. The phenomenon of doing business in the name of God has spread to other parts of the world that include Africa. In treating this topic, I endeavoured to look at the PHD Ministries using secondary literature, participant observation and oral interviews to elaborate God business with first-hand experiences. The article is divided into five sections. These included the historical development of prosperity gospel, the foundation of PHD Ministries, the approaches of PHD Ministries, reasons why people are attracted to PHD Ministries, brief assessment of PHD Ministries and pastoral and spiritual recommendations. The aim of the article was to look at god business in the PHD Ministries through theological lenses. It sought to prove how religion had been used to make a multimillion dollar enterprise. The PHD Ministries portray wealth and health as the aim of Christianity which God promised. It shows that God only blesses those who sow the seed and believe. But according to Scripture, God blesses unconditionally. There is a narrow approach to interpreting Scripture, and as a result the minimised meaning and application of the texts are used to propagate the prosperity gospel.
\end{abstract}

\section{Introduction}

The phenomenon of God business is generally thriving in the world and Zimbabwe in particular. ${ }^{1}$ According to Bishau (2013:65) this is known by various terms, each implying a different set of meanings and characteristics of the Gospel. Some of the pastors like T.D. Jakes, Chris Oyakhilome and Bishop David Oyedepo are among the top 10 richest pastors who own the most expensive mansions and private jets. ${ }^{2}$ The same is true with some pastors like Paseka Mboro and Shepherd Bushiri in South Africa and Walter Magaya of Zimbabwe. Hence, the core of our research is God business in Zimbabwe. I investigate its origins and biblical teaching on prosperity or wealth accumulation. The article intends to critically analyse the financial thriving in the Prophetic Healing and Deliverance (PHD) Ministries.

Webster (1998:1013) generally defines prosperity as a prosperous condition, material well-being and success. The same scholar also defines the Gospel as the story that brings good news about Jesus as the Lord and Saviour of the whole world (Webster 1998:545).

The greatest challenge is the rift that has risen between people and the actual message of Jesus Christ. People are now attracted to the message of wealth and health more than Jesus himself who is the source of all that is good. The prosperity gospel attracts many members from all walks of life. Although some people claim to belong to mainline churches, they also Nicodemusly attend the services where they receive health and wealth.

1.This article is based on the field research work carried out between January and August 2016 in Harare, Zimbabwe, and for various short periods after that.

2.The pastors of internationally established churches are very rich. They own vast properties and a lot of money. This is why even some politicians fear them and ask for their support during elections. The prosperity gospel is called by several names that include: health and wealth gospel, Gospel of greed, etc. (Adeyele, 2nd October 2015:1). T.D. Jakes strongly argues for the propagation of the prosperity gospel. According to Jakes poverty is a barrier to living a full Christian life. This was affirmed by the co-researchers who argued that they would not like to be poor. For Bishau, 'Poverty is not an option'. 


\section{Method of approach}

There are many books, articles, journals and websites, which are available either supporting or opposing how some pastors are using the name of God to amass wealth for themselves. The researcher has had the privilege of reading many of these resources and attained substantial knowledge on the subject under discussion. Qualitative research was conducted among the members of PHD Ministries located in Harare where the church is headquartered. The qualitative method aims to provide information on what people say and how they behave (Steyn 2007:11). There was a practical aspect of data collection, which was achieved through participant observation and interviews with members of the PHD Ministries. The advantages of this method are that the researcher obtains primary evidence from people concerned and is able to relate the data with insights from other sciences. These sciences include psychology, sociology and history. The languages commonly used during the services are English and Shona. Members are mostly Zimbabweans and some foreigners from South Africa, Botswana and Zambia.

The collection of data consisted of contacting members of the church by making an appointment to see them or having a conversation telephonically. Secondly, the researcher performed participant observation by minimising intrusion. Thus the researcher exercised empathy without bias or preconceived ideas about the church. The prophet and his advisors were not aware of this research objective. The method of selecting interviewees was mainly based on 'snowballing' where one member would suggest someone else who had been healed or delivered from a particular problem. Thus I avoided the use of a particular category of people or health problems. I conducted 50 in-depth interviews (34 women and 16 men). Thirty-six interviews were conducted among the Shona people, and only 14 were foreigners. Some interviews were conducted at the church or homes of the interviewees. In the same line of thought, Nunez (2015:149) states that the use of participant observation is oriented to learn about the contents and meanings contained in healing interventions, teaching and to obtain an insider view of how people engage in church activities. The purpose was to witness and see how the prophet heals or delivers people from many problems afflicting them. Compounded to this, the intention was to establish how people contribute money to this church.

\section{The historical development of the prosperity gospel ${ }^{3}$}

The genesis of prosperity gospel churches goes back to the USA in the early twentieth century. As is chronicled, "The founder of the prosperity gospel "faith movement" was Ur. Essek William Kenyon (1867-1948), a pastor and founder of Bethel Bible Institute' (Kroesbergen 2014:5). Kenyon was an

3.The main focus is primarily on material possessions, physical well-being and success in this life, good health, clothes, housing, cars, promotion at work, success in business as well as other related endeavours of life. ordained Methodist minister. He later on left Methodist ministry and founded several churches which he linked to the Baptist church (Kroesbergen 2014:5). It has to be borne in mind that although Kenyon had a good relationship with the pioneers of the Pentecostal movements in the USA and leaders in other continents (Walker 2007:252, 347), in fact he never accepted all their teachings and doctrines.

Subsequently, Kenyon came in touch with the ideas and teachings of the 'New Thought' which was founded by Phineas Parkhurst in 1838. According to Parkhurst, the mind has the ability to heal the body (Kenyon 1968:30; Walker 2007:237). Kenyon was also influenced by the Christian Science movement which was started by Mary Bakes Eddy. According to Eddy, sickness, sin and death are illusions and thus can be cured through right thinking (Martin 2003:149-155; Walker 2007:100).

Kenyon taught that Christians could make a positive confession to bring emotional and physical desires into being (Kroesbergen 2014:6). He stated that what one possesses, he or she should possess. Commenting on prosperity theology, Norberto Saracco argues that Kenyon believed that the spread of his teaching about the power of the human mind to overcome sin and sickness would result in human beings who would not be affected by evil spirits or by illness or poverty (Saracco 2007:323). This teaching had influence on the Pentecostal beliefs of Kenneth Hagin (19172003). Furthermore, 'He added Kenyon's teaching to his own to create what would become the Word-Faith movement' (Kroesbergen 2014:6). As a pastor, Hagin taught Christians that they could get rich if they had enough faith. He preached that words spoken in faith related to health and wealth must be fulfilled because God is required to honour the words (Hagin 1987:14ff.). Thus Hagin urged his believers to 'say it, do it, receive it, tell it' (Walker 2007:323). Consequently, Hagin is recognised as one of the fathers of prosperity movements.

It is Kenneth Copeland (1936- ) who helped to restructure and organise the prosperity gospel movement. Copeland began teaching in the 1960s that faith is a force which brings material results when confessed aloud. Walker (2007:90, 347348 ) argues that within a couple of decades Word-Faith grew into a significant offshoot of charismatic faith. The same scholar also adds that other word-faith teachers include Kenneth Hagin Jr, Gloria Copeland, Charles Capps, Creflo Dollar, Fredrick K.C. Price, Paul, Jan Crouch, et cetera (Walker 2007:348).

The most important question is how the prosperity gospel found its way into Africa, and Zimbabwe in particular. It is argued that the prosperity gospel movement was planted in Africa through African Initiated Churches (Mulhin 2008:211212; Walker 2007:252-253). In the 1950s Kenneth Hagin, his son Kenneth Hagin Jr and Kenneth Copeland visited African Initiated Churches across Nigeria preaching the prosperity gospel (Kroesbergen 2014:7). The impact was so immense that these churches grew into millions of members. Thus the 
gospel of wealth found its way into the heart of Africa. Many people began to believe that God grants prosperity to all believers who have enough faith. In other words, religious faith is very important to economic success.

Another contributing factor was the rise of television evangelism. In the 1960s the prosperity gospel teachers dominated televangelism. And when Africans had access to TVs they used to watch the American programmes. This later influenced African prosperity gospel teachers to develop their own channels which are watched by millions of viewers across Africa.

\section{The Foundation of Prophetic Healing and Deliverance Ministries}

The PHD Ministries is one of the newest Christian movements in Zimbabwe. Prior to it there was United Family International Church, founded by Emmanuel Makandiwa, and the Spirit Embassy which was started by Uebert Angel. Lately there is Walter Magaya who founded the PHD Ministries. All three of these trace their origin to T.B. Joshua of Nigeria. He is their spiritual father to whom they pay homage.

The PHD Ministries was founded by Prophet Walter Magaya in October 2012. It came to life after the prophet visited Synagogue Church of All Nations in Nigeria, which is led by Temitope Balogun Joshua (commonly called T.B. Joshua). This Nigerian prophet is called senior pastor and spiritual father by his spiritual sons like Magaya, Bushiri, Makandiwa, etc. T.B. Joshua anointed Magaya to the position of great prophet. Magaya was born in Mhondoro Ngezi in the Harare Province. He grew up as a member of a Catholic charismatic group called Blood of the Lamb Christian Community. What is clear is that Magaya visited T.B. Joshua to seek business guidance but the exact number of business projects is not exactly known because Chibango (2016:61) states 16 proposals while the church website says they were eighty (80). T.B. Joshua guided Magaya to become a prophet.

On his return from Nigeria Magaya found people waiting for him at the airport. He started with 45 members. Later the number grew larger. As Chibango (2016:62) writes, 'The services are attracting an average of 350000 congregants'. But the number can be bigger than this especially on Sundays and all-night prayer sessions when people flock from various countries.

\section{Lifestyle of the prophet ${ }^{4}$}

Although this characteristic is not explicitly pronounced, it is implicitly implied. In a country like Zimbabwe where poverty has become the order of the day, prophet Magaya is considered a celebrity. His lifestyle has caught the attention of many people who look at his background and upbringing. According to Jenkins (2006:75-78), the lifestyle of prosperity

4.The prophet belongs to the affluent community. He owns a lot of buses, cars, vans and properties. By the time the Zimbabwean government was introducing Bond notes they begged prophet Magaya to accept and convince his congregants to do the same as well. gospel preachers is corrupt and lavish. Prophet Magaya has many properties in affluent areas around Harare, Zimbabwe. The project worth billions of dollars which is undertaken by his company Planet Africa shows that he is now a rich prophet. The cars, buses and houses he owns are a clear testimony that the prophet is financially stable. According to the co-researchers (interviews with members of the congregation, 6th May 2016, Waterfalls, Harare), every Sunday the prophet collects a lot of money (an average of $\$ 300000$ USD). All-night gatherings tend to be fundraising rather than Gospel preaching. The prophet is far richer than his surroundings.

\section{Factors that gave rise to the growth of Prophetic Healing and Deliverance Ministries Economic meltdown and political crisis in Zimbabwe}

The Zimbabwean economic crisis has been entered in the Guenness Book of World Records. The period of Global Political Agreement saw a slight economy recovery, but now the situation has deteriorated further. Currently, the Ministry of Finance has been struggling to pay salaries of civil servants (June and July 2016). In other words, there are no pay dates anymore. In June 2016, civil servants were paid \$100 for transport, food, et cetera. To date all lecturers at state universities have not been paid bonuses as of 2015. This has seen an increase of poverty. The country has a high unemployment rate. This has been coupled with closure of many companies in the past years. A survey carried out by the Zimbabwe Commission of Trade Union (ZCTU) in 2014 revealed that over 75 companies had closed in 2013, leaving 9000 people jobless. It is estimated that between 3 and 4 million people have left the country (UNDP 2010).

\section{Deterioration of health delivery system versus miraculous healing}

Simple logic shows that when the economy is in shambles nothing that depends on it moves on. The same is true with the health department in Zimbabwe. Chibango (2016:61-62) affirms this when he writes, 'The delivery of health care services remains scanty in the country due to lack of adequate medical facilities, shortage of drugs as well a lack of medical personnel'. Many skilled personnel have left the country for greener pastures.

The above crises have been fertile ground for the gospel of prosperity to grow maturely. It is against this background that prophets like Magaya have come claiming to solve the problems listed above. The issue of miracle healing plays a central role in the PHD Ministries. 'It is believed that through the working of the Holy Spirit God rewards the faithful with spiritual and physical healing' (Gbote \& Kgatha 2014:6). Miraculous healing involves healing from physical sickness, mental retardation, spiritual attacks and socioeconomic problems. In most cases the congregants are asked 
to portray pamphlets with written diseases. Others are chosen to give testimonies of healing in gathering to show that the prophet is very powerful. As written in the name of the church, another term used for healing is deliverance. Deliverance entails that circumstances and spirits that obstruct the progress of someone are removed or prevented. In addition, the testimonies publicise that the prophet is capable of casting out evil spirits and healing people. This makes the prophet famous because people believe that he can speak to God directly and has power to say anything that becomes true. According to Jenkins (2006:104) healing and deliverance are based on the interpretation of Ephesians 6:12, which states, 'For our struggle is not against flesh and blood, but against the rulers, the authorities, the powers of this dark world and against the spiritual forces of evil in the heavenly realms'.

Consequently, many terminally sick people abandon their medication with the belief that they have been cured. Some abandon medication for fear of being labelled that they have little faith. This has caused many people to lose their lives. But nowadays the church has set up a health department that takes care of administering medicines to the sick.

In light of the above, another feature that dovetails with miraculous healing is prophecy and revelation. During church services the prophet claims that he receives special visions from God. As such when he speaks he says, 'I command, I foresee or I foretell'. The prophet speaks with divine authority to his audience. On 08 May 2006, prophet Magaya told his audience he sees a plane carrying 45 passengers crashing in the middle of Africa around Democratic Republic of Congo. Inside the plane there would be a prominent person whose name has Rand E. On the same day the prophet asked the congregants to take note of 02 September 2016 because something special is going to happen for Zimbabwe. In order to support this argument the prophet argued that he had foreseen the death of a Cameroonian footballer Patrick Ekeng. But this raised eyebrows because it looked like the prophet could foresee disaster without rescuing the situation.

\section{The approaches of the Prophetic Healing and Deliverance Ministries Sow a seed ${ }^{5}$}

The seed faith doctrine that has become popular in Zimbabwe is not a new phenomenon at all, but a fulfilment of the famous adage that what goes around comes around, and so history repeats itself (Bishau 2013:66). This is a concept that the church uses to raise money for its ministry. When congregants are told to sow the seed they do not hesitate to contribute financially to the prosperity congregation because they believe by doing so they will receive blessings from God (Robert 1975:34). At the end congregants compete for God to hear them individually. Thus financial contributions are prerequisites for God to solve human needs. This stimulates the congregants to support the prophet with money in a kind of competing style because each wants recognition by the prophet. And to be recognised by the prophet is to be recognised by God who heals and rewards through the prophet. Some people feel deceived when financial breakthrough fails to take place.

According to Prophet Magaya, 'If you contribute less, do not expect God to answer your prayers. God answers those who put more. Put more and become rich, richer and richest' (Homily, April 2016). The prophet further stipulates that failure to venture into business was tantamount to stupidity (Chibango 2016:65). For Magaya, a person who relies on a salary is daft.

\section{Self-supporting projects}

It is a well-known fact now that, 'Magaya has afforded to build himself an empire- a clear evidence of material prosperity, even amidst the current socio-economic crisis' (Chibango 2016:68). On 27 July 2015 the prophet bought a book chronicling the life of Grace Mugabe for \$50 000-00 (The Herald, July, 27 2015:1). Above all the prophet owns several assets that include Yadah TV, a channel to propagate televangelism, guest houses for congregants, residential estates and soccer teams for both males and females and a stadium. In 2015 Magaya announced he had opened a \$10 billion business company which would carry out various projects that include mining and construction. The company is called Planet Africa. It is sponsored by Yadah TV and Tahila Praise in South Africa (http://www.tadagtv.org/). Planet Africa has also ventured into housing projects. At present the company is building houses which will be let out upon completion. Although Chibango writes that the project was officially launched by the Principal Director of Local Government, Public Works and National Housing, the script at the entrance shows that it was the Minister Ignatius Chombo who officially opened this project and who promised more land to the church because it augurs well with indigenisation policy.

There are guest houses located in low-density areas of Belvedere, Marlborough and Borrowdale, which are owned by the church (see Figure 1). These houses are a source of income for the prophet. It is advertised that one has to book at the guest house for $\$ 300$ in order to see the prophet one-onone, but in reality this does not take place. The prophet meets people as a group and only gives them individual blessing.

Apart from the guest houses, the church has several farming projects around the country, which include poultry, agriculture and a building company. In addition, there are various church products which are sold to raise money. These include caps, T-shirts, wrist bands, booklets, anointing oil and stickers. Although some things are said to be free, they are in fact sold. For instance, anointing oil is labelled to be free, but it costs $\$ 25$. It could be a marketing strategy to sell their products. All these products bear either the name or picture of prophet Magaya. 


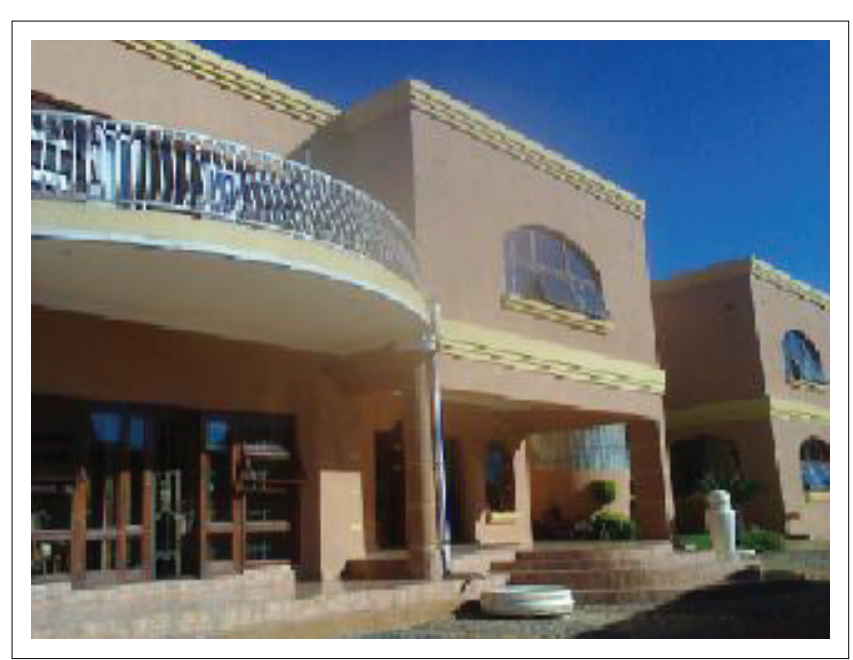

Source: Photo taken by author

FIGURE 1: One of the Guest Houses in Harare Low Density.

It is believed that prophet Magaya has supernatural power to create reality by speaking a word. This faith in the prophet gives people hope that distance does not matter. Hence they can be healed or receive blessings by following the prophet on TV or touching the screen.

\section{Partnering with Yadah TV}

To partner with Yadah TV means that one is in partnership with the prophet's vision and mission. It is an act of giving to the house of god for the support of God's ministry. As is stated, 'Being a Partner means you are equally concerned with the spreading of God's Word to all places'. As such a partner becomes a very important person who is different from other ordinary congregants. The church encourages members to commit themselves with the resources they have (time, financial or material) that the word of God may progress. And Luke 6:38, which says 'Give and it will be given to you. A good measure, pressed down, shaken together and running over, will be poured into your lap. For with the measure you use, it will be measured to you', is quoted to encourage people to be cheerful givers to PHD Ministries.

\section{All-night prayer gatherings ${ }^{6}$}

Every now and then the prophet sets dates for all-night prayers depending on how the Holy Spirit has inspired him. These gatherings can be only for women, men, youth or the sick. Hence they have different themes. They are considered to be extraordinary events. For instance, prophet Magaya in setting a men's all-night prayer date said, 'The date is going to Friday 29th of April 2016, and it will be a different day than any other days'. In the past he set up dates under the theme 'Night of Turnaround'. The theme has been running for a number of times and pulled large crowds. Another theme which has attracted many people was 'Creating Man with Power'. 6.It is only the prerogative of the prophet to announce the date for all-night prayer
sessions. This is based on how he has been inspired by the Holy Spirit. This takes place once in a while.

\section{Use of anointing oil}

The prophet encourages his followers to use his anointing oil. He teaches that anointing oil is a symbol of God's healing and delivering power. The church stresses that 'It is a point of contact in spiritual warfare and is a symbol of the Holy Spirit' (Magaya 2016b). ${ }^{7}$ It is further stipulated that the anointing oil protects from deadly dangers and traps. More so, it also cleanses and purifies an individual. The anointing breaks the bondage, burden and oppression caused by the devil (these include sin, poverty, diseases and limitation). In his Grace of All Time (Magaya 2015b:1) Magaya calls it the blank cheque anointing. In short, anointing oil heals, consecrates, sanctifies and provokes divine intervention. Hence it can be applied on all affected parts of the body and even documents like business proposals.

In Zimbabwe, God business poses a threat to mainline churches in this century. Apart from the element of numerical figures, the issue at stake is ecclesiological in nature. There are a lot of distorted biblical principles. This is a terrifying spiritual development. What comes out clearly is, 'Proponents of the prosperity gospel preach physical wellbeing that is measured by the amount of wealth an individual has' (Kroesbergen 2014:4). This includes good food, clothing, cars and houses. It can be noted that how someone acquires wealth does not matter because people are told that all blessings are received by faith. The prophet promises health and wealth and people believe they will receive. In April 2016 , the prophet prayed that all congregants get their wallets and pockets full of money (US\$). One congregant testified that she received $\$ 350$. This was similar to what prophet Makandiwa did when he prayed for people to get gold from heaven. Although on both occasions some members testified that they received money or gold, the majority went home empty handed.

The issue of health and wealth has not been fairly treated in mainline churches. The unequal distribution of wealth in many countries contributes to many people flocking to the prosperity gospel churches. Many feel attracted to PHD Ministries because of testimonies they see on Yadah TV or when they visit the church and attend the services.

The prophet has never visited rural areas with people who have no money to sow the seed. As such this church has remained an urban-centred church, mainly in Harare and other places of affluence. Other people are advised to follow the prophet on TV or converse with him telephonically.

\section{Giving testimony}

Another tool used to popularise the PHD Ministries is through testimonies. This is a feature in which congregants

\footnotetext{
7.The centrality of anointing oil in the church is shown in that at the centre of each booklet there is a section that teaches on the use of anointing oil. It teaches that use of anointing oil provides with overflow and abundance. The use of oil is based on Psalm 23:5. However, there are many Scriptural texts that are referred to in support of the use of anointing oil, like Jeremiah 5:14, Psalm 92:10, Mark 6:13, Exodus 29:7 Exodus 30:25, 31-33, Exodus 40:9, Matthew 6:17, Hebrews 1:9, 2 Kings 9:6, 1 Samuel 10:1, and Leviticus 8:10.
} 

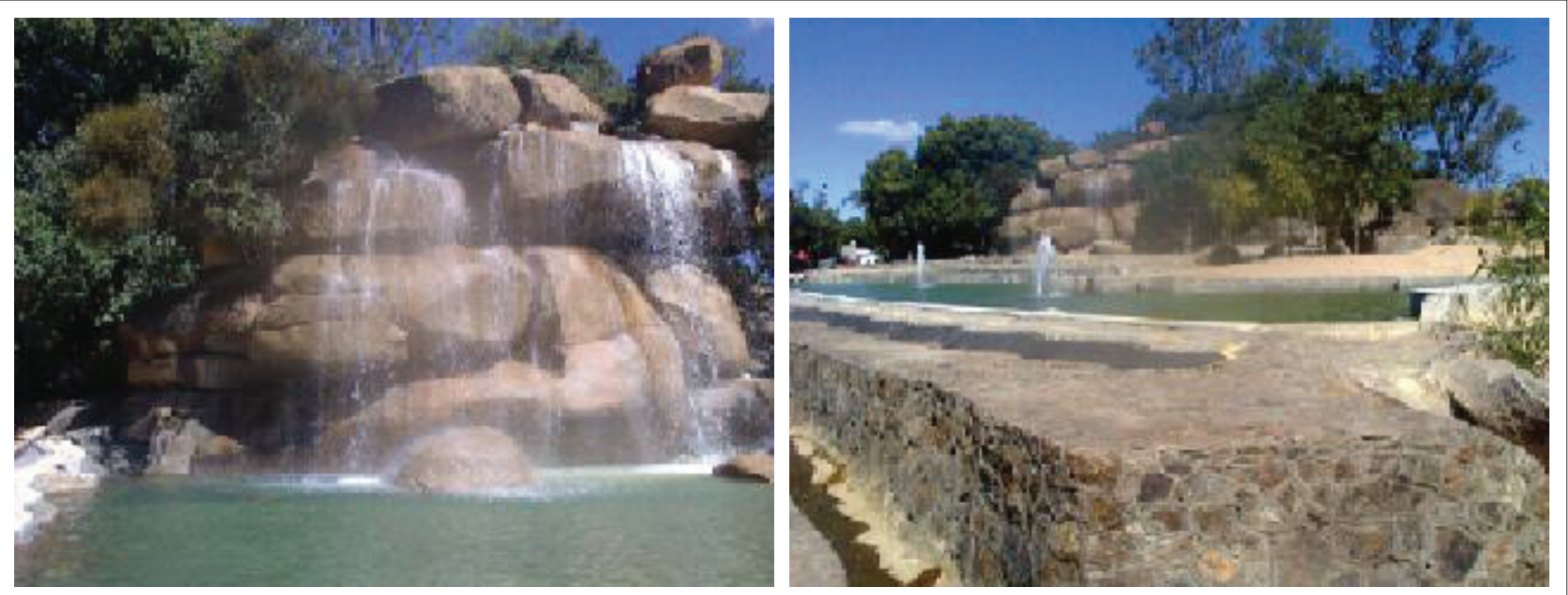

Source: Photos taken by author

FIGURE 2: Some sites at the Holy Mountain in Waterfalls, Harare.

testify to the manifestations of God's power in their lives during church services (Gbote \& Kgatla 2014:7). At these functions some selected people relate how God answered their prayers through the prophet in terms of health or wealth. On 08 May 2016 some people testified of skin healing, finding a good house or job and abandoning drugs and lives of loose morals. All these blessings were attributed to the power of the prophet Magaya who had cast out the evil spirits in previous church services. The evil spirits used to impede progress in their life. The material success is attributed to the prophet's call to sow the seed.

These testimonies sensitise other congregants to like the church and also sow the seed. The testimonies are always success stories. The congregants testify their dark past and their bright present situation. All is to portray that when one sows a seed he or she will succeed in life. De facto their present situation has been made possible through the prophet. The testimonies attract people in similar situations to be delivered.

\section{The practical and problem-solving approach}

The most important aspect of the PHD Ministries is not about predicting the future when compared to healing activities. Prophet Magaya is believed to be able to use the power of the Holy Spirit to heal the sick by laying on hands, anointing with oil or giving holy water. In concrete, the PHD Ministries offers tremendous promises to many sick and poor people. Thus traditional teaching on the practice of mortification, fasting and carrying of the cross do not appeal anymore. This is why 'The promise of prosperity is hard to resist' (Kroesbergen 2014:11). The promises attract many people because for so long people have been taught to endure suffering because they would get rewarded in heaven.

The worshipping services in PHD Ministries have incorporated many African traditional elements. These include oral liturgy. There is a spontaneous way of worshipping and not mere repetition which sometimes is a routine repetition. The aspect of giving testimonies instils confidence and attracts others to wish to do the same. The services are characterised by participatory worship and entertainment. A number of both Gospel and secular singers are invited to play music before the service by the prophet. In this case, this has attracted many young and old people. This allows people to let out the steam of their problems. Moreover, allowing people to exchange greetings and wish each other healing and blessing inserts congregants in a reconciliatory mood. The liturgical dance and prayers of healing and exorcism have an African cultural influence.

Another important reason why people feel attracted to the church is that it reflects the African way of blessing. According to Mugambi and Wasike (1992:60) to be blessed is biological and material. This is when people have access to land, bear children, many domestic animals, good health, good harvest and other related wealth. All these are blessings from the Supreme Being. This responsorial acclamation suffices, which states, 'Mbiri Kunani?' [Glory to whom?], and people respond 'Mbiri kuna Jesu' [Glory to Jesus].

At PHD Ministries ushers and novices encourage congregants to pray for themselves before the services by the prophet. At times people are asked to be angry with the devil, evil spirits or anything that hinders one to progress in life materially. Hence some slogans are chanted several times. For instance, people say, 'You spirit of poverty, HIV, cancer, etc. come out'. This repetition takes more time than the one the prophet spends with people. This can be done at the holy ground, which is adjacent to the main church or at Holy Mountain (see Figure 2). ${ }^{8}$ The environmental setting at the holy mountain is suitable for sacred activities. It is naturally designed, and this fits the African sacred sites where people go to ask for rain, healing and blessings.

8.The holy mountain is a small natural hill that has been beautified with flowing water,
flowers and nice buildings. The prophet intends to keep sharks at the place to attract flowers and nice buildings. The prophet intends to keep sharks at the place to attract
many tourists. The place is in the low density area of Waterfalls, Harare (see Figure 2). 
At the Holy Mountain and holy ground some people manifest. ${ }^{9}$ According to ushers, all the lodges have been blessed by the prophet and so are holy. Thus if you wish to have something in life and then touch anything at this place the prophet will grant it to you. It should be acknowledged that sometimes the emphasis is exaggerated such that people scramble to fetch soil or sand from all these places mentioned. Actually, people would grab anything that is associated with the prophet.

The church attracts the poor because they want to be rich. Healing influences people in many ways. 'It builds the faith of those who attend' (Theron 1999:57). The sick want to be healed. Some politicians want to enhance their status in society. The rich want to sow seeds so that they accumulate a lot of wealth.

The church meets the psychological needs of many people. In this context, people hear what they expect to get. They learn that, for a financial contribution, they can submit a prayer request with money to the prophet and he will pray for them. The promise that the prophet will pray satisfies them. Hence the prophet encourages the congregants to say, 'I receive'. People are promised healing, husbands, wives, houses, cars, etc.

The movement encourages people to be innovative and work hard during the time of hardships. The church has contributed to economic growth by employing more than 1000 people. Even the lifestyle of ushers and the security shows that they are paid well. The type of cars and clothes are of expensive value.

\section{The ecclesiology of Prophetic Healing and Deliverance Ministries Sowing the seed}

The chief characteristic of any prosperity movement is sowing a seed. In other words, faith results in health and wealth. In this case God wants his people to be blessed by security and prosperity. Conversely, sickness and poverty are curses to be broken by faith. Hood (2004:57-65) argues that the doctrine teaches that faith, positive speech and donations to the church's ministries will increase one's material wealth. The major teaching is that church members should give money to the prophet for their prayers to be answered by God.

The church teaches that poverty is a curse (cf. Dt. 28:1). In addition, it is argued that God blesses those who live upright and keep his covenant. Scripture is quoted to augment the doctrine. In its statement of faith, PHD Ministries underscores that those who believe in Jesus will have rest as stated in Matthew 11:28-30, 'Come to me, all you who labour and are burdened, and I will give you rest. Take my yoke upon you and learn from me, for I am meek and humble of heart; and some people can manifest at lodges. The church has trained personnel who assis people who manifest. you will find rest for yourselves. For my yoke is easy, and my burden light'. Thus the church argues that Jesus declared, 'According to your faith will it be done to you' (Mt 9:29). Also, Psalm 112:3 confirms this, saying, 'Wealth and riches are in his house, and his righteousness endures forever'. Another text used to support the argument is Ecclesiastes 5:19.

Joshua 1:7-8 states that if you follow God you will receive blessings when going out and coming in. In addition, it is argued, 'For no matter how many promises God has made, they are "Yes" in Christ. And so through him that "Amen" is spoken by us to the glory of God' (2 Cor 1:20). Prophet Magaya emphasises that God did not create poverty, but it came as a result of the fall of men (cf. Gn 3:1). In other words, God does not want his people to live in abject poverty. Rouse (1999:115-117) cites other biblical texts used to support prosperity gospel (e.g. Lk 6:38, Gl 6:7 and 2 Cor 9:6-8). All these are used to justify that congregants should pay tithe and support the vision and projects of the prophet with money in order for them to receive God's financial blessings.

To sow a seed means that when you contribute financially, you plant a seed which will multiply and return to you in abundance. As such, financial contribution makes one recognised and answered by God. Therefore, one gets an identity through the amount of money he or she contributes to the church. 'Anything that is spent in the Lord's service is believed to have rich returns' (Chibango 2016:59). This has brought the concept of the law of increase or the law of sowing.

The idea of tithes is biblically based. The main goal of PHD Ministries is to bring physical, spiritual and economic deliverance to all who are oppressed by the devil, based on Mark 16:15-18. The underlying teaching is Mark 10:29-30. This text is used in the context that we receive from God a hundred times what we put into his hands. This means financial contribution is what makes one enter into a cycle of endless wealth (Saracco 2007:323).

The above idea is coupled with the doctrine of prosperity. Prosperity has been a major teaching of PHD Ministries. This concept is understood as being successful and thriving in all areas (Hollinger 1988:134). To be successful involves physical, spiritual, financial and mental stability. It is a blessing from God when one possesses all these.

\section{One has to believe that he or she will receive}

According to Hollinger (1988:135), this is called positive confession. Thus, healing and prosperity are primarily realised through positive confession. This concept is understood as a statement made in faith. It lays claim to God's provisions and promises. For example, to be rich, one should pray in faith with a positive affirmation that he or she is rich, even if the symptoms of poverty linger on. Quoting Mark 16:17-18 the PHD Ministries teaches that a believer can possess anything he or she wants. In one of his sermons 
Magaya taught, 'Just believe and receive! You can have anything you want as long as you are willing to give up the belief that you can't have it' (Magaya 2016a:1). In tandem with this assertion, Magaya (2015:1) adds, 'When God says, Yes, no one says, $\mathrm{No}^{\prime}$. The church puts emphasis on the fact that people should testify good things that have happened to them in terms of health and wealth. As such placards are used to publicise what God has done to others. According to the ushers the papers inscribed with different diseases are meant to draw the attention of the public and not the prophet because he knows everything. As one usher retorted, 'Do you know the prophet you are talking about, he knows everything and these papers are just there to draw the attention of other people watching the $\mathrm{TV}^{\prime}$. In fact, the purpose is to show the tangible effects of prophecy and the power of the prophet to the whole world.

\section{Power of blessing}

The divine authority of prophet Magaya is never doubted or questioned in the church. Consequently, whatever the prophet says is believed with faith. The prophet teaches that when he has declared one to be a millionaire he or she should believe it. Hence he says, 'What I declare no one can say No'. This is why distance does not matter for one to be healed or blessed by the prophets. The power of blessing is backed by many scriptural texts like Deuteronomy 8:18 which states, 'Remember then, it is the Lord, your God, who gives you power to acquire wealth, by fulfilling, as he has now done, the covenant which he swore to your fathers'. Also Psalms 105:37 says, 'He brought his people out, laden with silver and gold; no stragglers among the tribes'. Matthew 6:33 confirms the above when it says, 'But seek first the kingdom of God and his righteousness, and all these things will be given you'. Furthermore, the PHD Ministries teaches people to believe in the power of the prophet. This is why congregants who play the DVD of the church or watch the Yadah TV channel from far distant places can be healed and be blessed by touching the screen. This is in congruency with Proverbs 10:22 which says, 'It is the Lord's blessing that brings wealth, and no effort can substitute for it'. And also Psalms 1:1-3 augments the above argument.

This concept of blessing can be traced back to God's covenant with Abraham. Scholars of prosperity gospel argue that the main reason God made the covenant with Abraham was to bless him materially (Kroesbergen 2014:10). Therefore, Christians are heirs of the blessings of this covenant because they are children of Abraham. God wants all people to prosper in all areas of life. The inheritance of children includes possessing the best homes, cars and clothes (Saracco 2007:323).

\section{Some of the reasons why people are attracted to Prophetic Healing and Deliverance Ministries}

Many people are attracted to the church every week from all over the world. The healing power of God is by no means a novel teaching. 'Unemployment, housing problems and diseases are some of the issues that the movement claims to solve' (Chibango 2016:61). Most people go to PHD Ministries because they have a problem(s) to be solved. What is new in PHD Ministries is that the prophet uses a different approach of healing and teaching. His homilies can be accessed prior to church services.

\section{Evil spirits Types of evil spirits}

Another area that has drawn the attention of many people to PHD Ministries is evil spirits. Spirits are psychic beings that are intelligent, purposive and personal. They are ranked hierarchically according to their power and role in ontological order in the world of spirits. Besides God and human beings there are spirits. There are many types of spirits. The spirits can either be identified with God or human beings. Spirits can be categorised as good or evil. In this article the focus is on evil spirits.

Evil spirits are believed to be the root cause of many problems people face and only prophet Magaya can cast them out. The spirits are classified into categories. There are spirits of poverty, diseases, death or infertility. Concerning the spirits of poverty, prophet Magaya teaches that such spirits have declared a war against the prosperity of people. They go against what God intended, for people to prosper, be fruitful and multiply (cf. Gn 1:28). Spirits of poverty plan against the happiness of human beings. Magaya (2015a:3) emphasises, 'Please take note, God does not cause a single problem in your life-all problems come from the devil'. In 2015 Magaya had a sermon dedicated to 'Breaking the chains of poverty spirits.' He taught that God is not poor and so is there to break the chains of poverty spirits. According to Chibango (2016:62), 'Magaya considers poverty to be a spirit that possesses poor people and which needs to be cast out ...'. The types of these spirits are linked to traditional beliefs. Hence many people want to be freed from such spirits. These spirits are believed to cause people to fail in business, lack of employment, failure to secure accommodation and other related challenges. The economic hardships endured for so long and unemployment push people to look for solutions from the prophet. While the poor look for jobs, houses or prosperity, the rich generally seek for protection of their money and properties. Hence they attend the teachings, preaching, prayers and services physically or through TV. The spirits of debts cause one to be addicted to borrowing throughout life. This limits the progress in life and needs deliverance. Health failure is the result of a spirit of disease. Many people want to be healed by the prophet. According to the movement the spirit of disease causes disabilities, HIV and AIDS, cancer, barrenness and other types of sicknesses. As such the prophet is the only one who can exorcise these spirits.

In addition prophet Magaya teaches about territorial spirits. According to him, 'Territorial spirits are a demonic occupation of a certain geographical area or location where location means area or territory, hence territorial' (Magaya 2014:1). 
Such types of spirits occupy certain areas like a district, province or village. These spirits are spiritual in nature in such a way that they cannot be visibly identified. Because they are evil these spirits are only identified with people or geographical places. Just as Jesus said by their fruits you will know them, people and places with territorial spirits are known by their deeds or actions, which include killing, hatred, stealing or prostitution.

Another category of evil spirits is of witchcraft and Satanism. In his treatise on witchcraft Magaya writes, 'Witchcraft goes back to the beginning of time and also existed during biblical times, no wonder it is mentioned in several sections of the bible being ridiculed' (2016c:1). People who possess witchcraft powers perform evil works. Because witchcraft and Satanism come from the devil, they are two sides of the same coin. Some people buy, inherit or are initiated into witchcraft. Their aim is either to kill or injure someone. There are animals associated with witchcraft like snakes, owls or cats. These animals are sent by their owners to harm other people. Witchcraft is usually practised at night.

\section{A brief assessment of Prophetic Healing and Deliverance Ministries}

After examining the positive contribution of PHD Ministries to the spiritual realm, we now look at various aspects that militate against theological teaching. Acknowledging that there are some positive elements within PHD Ministries does not exempt the researcher from providing a critical theological evaluation of some of its practices. The gospel of prosperity is mostly half-truth. Okoh (Christian Voice, July 9, 2013) describes it as half-truth sermons by pastors whose aim is for personal advancement and enrichment. In addition, Jones and Woodbridge (2011:18) affirm this when they also write, 'First, the prosperity gospel contains a grain of biblical truth, albeit a grain of truth that has been greatly distorted'. Saracco (2007) critically contends:

Passages such as Mark 10:30, 11:22 and 11:23-24 are key to the prosperity gospel, and interpreted by forcing their (the prosperity movements) arguments on the translation. For example, the hundredfold reward promised by Jesus in Mark 10:30 is not a formula for a personal enrichment but a show of God's love toward those who have left all for his cause. Even so, the same passage clarifies explicitly that these blessings will not preclude adversity. (p. 324)

Although prophet Magaya appeals to Scripture, one cannot overlook the narrow approach to the interpretation of quoted texts. The approach has little regard to the Bible in that it claims that Christianity is a religion that ought to improve one's economic standards. As observed by Kasera (2012):

This claim ignores the reality of the suffering that the majority of Christians around the world are faced with and it is not practically helpful in the cause of helping the poor both in the church and outside the church. (p. 121)

Scripture puts emphasis on faith and not on the audible expression of what we want to achieve. The words are flatus voci in themselves because it is God in his sovereignty who decides to bless or withhold material blessings.

\section{Moreover:}

God bless people, but it should be noted that immediate responses are not imposed induced or forced. In this way, we do not earn blessings by what we have sown. God does not owe us anything because $\mathrm{He}$ has given us more than we deserve (Morrison 2002:14). Blessings rest on the grace of God. (Saracco 2007:324)

The Webster's Ninth Collegiate Dictionary defines grace as 'unmerited divine assistance given man for his regeneration or sanctification'. Similarly, blessing is unmerited favour or gift (Packer 1981:94-95). Thus, blessings are something that God gives us or does for us or enables us to do that we did not in any way earn, deserve or merit. In the Old Testament, Abraham and Joseph did not demand blessings but did everything with faith and perseverance. This is what Jesus teaches in the New Testament.

In other words, PHD Ministries fails to differentiate the covenant of God with Israel that entailed some material blessings and the new covenant which also entails spiritual blessings and makes no specific promises of material blessing. In the old covenant, material blessings were not given to every individual. There were many poor people among the descendants of Abraham (cf. Ex 23:1-6). Hence that narrowing of the essence of Christianity to material abundance and physical well-being is a serious distortion of the Biblical message. A theology that minimises the importance of eternity in the Bible is earthly centred. At the end people serve the prophet and not their Creator.

It has been clear that the PHD Ministries acknowledges the reality of poverty and sickness. However, acknowledging the presence of suffering becomes obsolete if solutions offered are based on quasi-magical faith, positive confession and seeding to escape poverty or any suffering. Looking at the situation in Zimbabwe, poverty is very high in churches, and there is need for well-thought-out theological response, for instance coming up with structures on assisting the aged, widows and orphans.

It has been observed that the church takes advantage of people with limited education, little financial resources and intellectual reasoning. As noted by Theron (1999:14), there is manipulation, excessive claims and simplistic use of Scripture to deceive people. Most of the people who attend PHD Ministries have little understanding of Bible teaching. Hence they offer everything to the church so that they receive material blessings from God. De facto they focus more on the prophet than Jesus Christ who heals and blesses. The prophet has become more famous than God. But Jesus said, 'So you also, when you have done everything you were told to do, should say, We are unworthy servants; we have only done our duty' (Lk 17:10). Another critical point is of selling books, videos, oils, water and accommodation fees which are so exorbitant when we 
consider that most people in Zimbabwe live at or below the poverty datum line (Brooke 2011). This impoverishes the poor further. Moreover, the prophet does not problematise poverty, instead he problematises the poor. Thus, 'It implies that the poor are faithless and warrant no sympathy ...' (Brooke 2011:34).

In following Jesus Christ, there are two extremes to be avoided. The first one is to think that having material things is very bad. And the second danger to avoid is that extreme possession of material things proves God's goodness. The latter position has made people to see Christianity as a means of obtaining the best things offered in this life. It paints a doctrine of the greedy rather than the needy. People are attracted by material blessings. Piper (2010: 24-25) opines that such an approach does not awaken the spirituality of people but only focuses on the greedy. The teaching of health and prosperity appeals to seeking wealth without properly reducing poverty in the society. Abogunrin (2007:269) writes, 'Rather, it can make Christians to be lazy in their attitude to labor'. It looks like the kingdom of God is very easy. Members of the PHD Ministries are formed to believe that good life consists of owning new houses and fancy cars, whereas Christ calls people to experience a different kind of abundance in the here and now. This ignores the fundamental aspect of sacrifice and using the narrow gate. Jesus said that if anyone wishes to follow he or she carry his or her cross all time. Avoidance of suffering is contrary to the Christian teaching and the problem of evil. As observed by Jones and Woodbridge (2011:15), the prosperity gospel omits Jesus and neglects the cross. The story of Job and the suffering Messiah show how the innocent suffer but for a purpose.

The common phenomenon among these preachers is the heavy presence of security around them. Their trade mark is black suits and visible signs of seriousness. In the PHD Ministries, when the prophet is moving up and down the security over-protect the prophet such that they push down people who seek to get his attention. In most cases there is role confusion between the security and ushers and photographers who fight to get near the prophet. Hefner (2016) proposes a balance between security and worship at church. As such the prophet should not allow fears to overcome his faith in God's protection. But this is not undermining the need for security.

The prophet is the leader and an administrator of his church. Interviews with the members of PHD Ministries showed a concern over lack of leadership, mentorship or a succession programme. Barentsen (2011:262) infers from 2 Timothy 2:1ff. that Paul shows a plan of succession through Timothy to other leaders. The same notion is orchestrated by Martin (1998:35) in the leadership of Moses to Joshua (Dt 31:6-8, 23; Jos 1:6-9, 18). In the event of death this creates leadership vacuum and split. Thus there is no succession plan. It is either the wife or child taking charge of the church. This portrays the church as a family business.

\section{Pastoral and spiritual recommendations}

- The church should go beyond theological teaching on poverty and prosperity reducing poverty in the country. Thus the church should team up with other churches and government to reduce poverty in Zimbabwe and not operate in isolation.

- Scripture should be understood in proper contexts which include history, geography and socio-political environment. Therefore, it is imperative that the original message should not be distorted or altered.

- There is need to distinguish prayer from demand. At times we have to work for ourselves and never treat God in a robotic way.

- Christians should have clear understanding of the identity and life of Jesus Christ. Jesus set an example of Christian life, i.e. to love others and sacrificing his life for them.

- Theological institutions should open up the understanding of current Christian trends.

- Mainline churches should pay attention to the daily concerns with due care.

- Pastors need to be trained in dealing with spiritual issues that trouble people. But preachers should not manipulate the Bible to their own financial advantages.

- Proper exegesis and interpretation of scripture should be re-invigorated. Nemo dat quod non habet [You cannot give what you do not have)].

\section{Conclusion}

From the above juxtaposition it comes out clearly that the interpretation of the bible is crucial in influencing followers to listen and obey one's commands. The message one preaches transforms people's perceptions of reality. The word of God is used for material gain. The article has shown that the prosperity gospel is a reality in the PHD Ministries. In the context of economic hardships people seek for solutions from whoever promises to offer them. In Zimbabwe, people flock to PHD Ministries so as to be healed from diseases and delivered from poverty. Like many other proponents of the gospel of prosperity, prophet Magaya teaches that evil spirits impede people from becoming rich. Hence he encourages people to be delivered from them (evil spirits). The church also encourages people to work hard and come up with new businesses under harsh economic conditions. In summary, God should be served without condition. This is why Paul wrote to Timothy saying, "Those who want to get rich fall into temptation and a trap and into many foolish and harmful desires that plunge people into ruin and destruction. For the love of money is a root of all kinds of evil. Some people eager for money, have wandered from the faith and pierced themselves with any grieves' (1 Tm 6:9-10).

\section{Acknowledgements Competing interests}

The author declares that he has no financial or personal relationships which may have inappropriately influenced him in writing this article. 


\section{References}

Abogunrin, S.O., 2007, Jesus' pronouncements on wealth in the context of the health and wealth gospel in Nigeria, The Biblical Studies and Corruption in Africa, The Biblical Studies Series, pp. 267-270, NABIS No., Ibadan.

Adeleye, F., 2015, The Prosperity Gospel: A Critique of the way the Bible is used viewed 26 Jan. 2017, from https://www.laausene.org/content/the-prosperity-acritique-the-way-the-bible-is-used

Barentsen, J., 2011, Emerging leadership in the Pauline Mission: A social identity perspective on local leadership in Corinth and Ephesus, Princeton Theological perspective on local leadership in Corinth and Ephesus,
Monograph Series 168, Pickwick Publications, Eugene, OR.

Bishau, D., 2013, June, The Prosperity Gospel: An investigation into its pros and cons with example drawn from Zimbabwe, viewed Feb. 2017 from htt://webcache.
googleusercontent.com/search?academia.edu/6023811/THE PROSPERITY gOogleusercontent.com/search

Brooke, G., 2011, The case for the prosperity gospel, May 25, Huffpost, New York.

Chibango, C., 2016, 'Prosperity gospel, a pathway out of a socioeconomic crisis? The case of PHD ministries of Walter Magaya, Zimbabwe', in Modern Research Studies, An International Journal of Humanities and Social Sciences 3(1), 55-82.

Gbote, E.Z.M. \& Kgatla, S.T., 2014, 'Prosperity gospel: A missiological assessment', in HTS Theological Studies 70(1), 1-10.

Hagin, K.E., 1987, Healing is for you, Harrison Publishers, Tulsa.

Hefner, R.W., 2016, Global Pentecostalism in the 21st century, Indiana Press, Bloomington, IN.

Hollinger, D., 1988, 'Enjoying God forever: An historical/sociological profile of the health and wealth gospel', Trinity Journal 9, 131-149.

Hood, N., 2004, God's Wealth: Whose money is it anyway, Carlisle, Paternoster.

Jenkins, P., 2006, The new faces of Christianity: Believing the Bible in the global south, Oxford University Press, Oxford.

Jones, D.W. \& Woodbridge, R.S., 2011, Prosperity gospel, health, wealth and happiness, Kregel Publications, Grand Rapids, MI.

Kasera, B.M., 2012, The Biblical and theological examination of prosperity theology and its impact among the poor in Namibia, South African Theological Seminary, Sandton.

Kenyon, E.W., 1968, Jesus the healer, Kenyon Publishing House, Seattle, WA.

Kroesbergen, H., 2014, In search of health and wealth: The prosperity gospel in African, reformed perspective, Wipf and Stock Publishers, Eugene, OR.

Magaya, W., 2014, Territorial spirits, Teaching by Prophet W. Magaya.

Magaya, W., 2015a, Breaking the chains of poverty spirits, we do not worship a poor God, Sermon by Prophet W Magaya.
Magaya, W., 2015b, Grace of all time, Sermon by Prophet W. Magaya.

Magaya, W., 2016a, Just believe... and receive, Sermon by Prophet W. Magaya.

Magaya, W., 2016b, Partake your miracle, Sermon by Prophet W. Magaya.

Magaya, W., 2016c, Witchcraft: Teaching, by Prophet W Magaya.

Martin, B., 1998, 'From pre- to postmodernity in Latin America: The case of Pentecostalism', in P. Heelas (ed.), Religion, modernity and postmodernity, 104111, Blackwell, Oxford.

Martin, W. 2003, The Kingdom of Cults, Bethany House, Minneaplois.

Morrison, R., 2002, A History of the American Prosperity Gospel, Oxford University Press, Oxford.

Mugabe, T., 2015, The Herald, July 27, Association of Zimbabwe Newspapers 1, Harare.

Mugambi, J.N.K. \& Nasimiyu-Wasike, A. (eds.), 1992, Moral and ethical issues in African issues Christianity: Exploratory essays in moral theology, Initiatives, Nairobi.

Mulhin, R.B, 2008, A Short History of Christianity, Louisville: Westminster John Knox.

Nunez, L., 2015, Faith healing, migration and gendered conversions in Pentecostals churches in Johannesburg, Springer International, Johannesburg.

Okoh, N., 2013, Christian voice, July 9, Uzii Diocesan Compund, Owerri.

Packer, J.I., 1981, Concise systematic theology. A guide to historic Christian beliefs, Inter-Varsity Press, London.

Piper, J., 2010, Let the nations be glad! The supremacy of God in the missions, 3rd edition, Baker Academic, Michigan.

Robert, O., 1975, Miracle of seed faith, Harrison Publishers, Tulsa.

Rouse, T., 1999, Faith and the pharisees: Sincere critics have been sincerely wrong about the word of faith teaching, Insight, Yale, MI.

Saracco, J.N., 2007, 'Prosperity theology', in Dictionary of mission theology: Evangelical foundations, edited by Corrie, J., (et. al.), Inter-Varsity Press, Nottingham, 209-213.

Steyn, R., 2007, Qualitative research methodology: The anthropological strategy, UNISA Press, Pretoria.

Theron, J.P.J., 1999, Towards a practical theological theory for the Healing Ministry in Pentecostal churches, University of South Africa, Pretoria.

United Nations Development Programme, 2016 Human Development Report, 2016, New York, viewed 03 Mar. 2017, from http://hdr.undp.org/en/data

Walker, J.K., 2007, The concise guide to today's religions and spirituality, Harvest House, Eugene, OR.

Webster, 1998, The new international Webster's comprehensive dictionary of the English language, Trident International, Naples, FL.

Yadah TV, 2017, Word Press, viewed 24 Jan. 2017, from http://www.yadagtv.org/ 